\title{
Cikkismertetés: A blogírás mint egészségműveltségi gyakorlat
}

\author{
Article review: Blogging as a Health Literacy Practice
}

Ismertetők: $\quad$ Nagy Gábor Zoltán $\varangle$, Osváth Mátyás

Debreceni Egyetem, Népegészségügyi Kar, Egészségtudományok Doktori Iskola, Debrecen

\begin{abstract}
Ismertetett cikk: Karlsson AM, Nikolaidou Z, Bellander T. Blogging as a Health Literacy Practice. Identity construction and knowledge-building in the writing of parents of children with heart defect. In: Hållsten S, Nikolaidou Z (editors). Explorations in Ethnography, Language and Communication - Capturing linguistic and cultural diversities. Elanders, Stockholm, 2018. pp 127-151. http://sh.diva-portal.org/smash/get/diva2:1193127/FULLTEXT01.pdf
\end{abstract}

Beküldve: $\quad$ 2020. 04. 21.

doi: $\quad$ 10.24365/ef.v61i3.583

Kulcsszavak: blogírás; egészségmúveltség; identitáskonstrukció

Keywords: blogging; health literacy; identity construction

\section{ELMÉLETI ÁTTEKINTÉS}

Az egészségügyi információk hozzáférésének és elemzésének képességén felül az egészségmúveltség magába foglalja az üzenetek különböző formában való közlésének képességét is. Az egészségügyi témákban írt blogok az egészségmúveltség növelésének egy módja, ahol az egészségügyi tudás gyarapítása nemcsak az olvasás általi információ "fogyasztását" jelenti, hanem a tudás írásbeli feldolgozását is.

A korábbi kutatások fókuszába kerülő egészségügyi blogok motivációi közé tartozik a problémamegoldás az érzelmek kezelése, a közösségépítés, az információmegosztás, a tanulás és a kampányolás az információ terjesztése, pénz gyűjtése és események megrendezése által.

Traumatikus stresszor vagy negatív esemény következtében elfojtott érzelmek és gondolatok írásban való kifejezése révén az egészség javulása érhető el. Az írás mint az önkifejezés eszköze a pszichoterápia során is régóta alkalmazott módszer, a korábbi naplóformátum pedig a technikai fejlődésnek köszönhetően kibővült a blogolás lehetőségével.
Ráadásul - miután a blogírás kétoldalú információcserét tesz lehetővé - az egészségügyi témájú blogokban az író tanácsot és támogatást is kaphat az olvasóktól, továbbá elérhet hasonló helyzetű egyéneket is. További pozitívum, hogy az író tagja lehet egy online közösségnek, ahol tudományos ismeretei új kontextusba kerülnek, és az egyén saját tapasztalatai mellett új tudást is szerezhet.

Az identitás folyamatként értelmezhető, amelyet az ember életében bekövetkező események és pillanatok formálnak, nem pedig mint "adottság" van jelen. Az identifikáció kifejezés a folyamatban megjelenő átmenetek megragadására is használható, így az identitás "főnévről igére" módosul. Az írói identitás alábbi aspektusait határozzák meg, amelyek az akadémiai íráson kívüli szövegekben is megtalálhatóak.

Az első az „életrajzi én” (autobiographical self), amely során a szerző élettörténete és tapasztalata határozza meg viszonyulását a témához. A második a szövegből kirajzolódó, vagyis „szövegbeli én” (discoursal self), amely a szövegben megjelenő én-reprezentációt jelenti, azt a benyomást, amit magunkról közvetítünk írás közben. A harmadik aspektus pedig a „szerzői én” (self as author), amely 
az írásban megjelenő tekintéllyel, az autoritás fokával van összefüggésben.

$\mathrm{Az}$ egészségügyi blogok elemzésében az előbb bemutatott, írás által megnyilvánuló identifikációs folyamatot használja a szülői identitás elemzésekor Karlsson, Nikolaidou és Bellander. Emellett a szerzők a blogok tartalmainak kutatása során négy tartalmi típust vizsgáltak: a szülők mindennapi élete a gyerekkel, az orvosi tények, az elköteleződés és az érzelmek kifejezése.

A blogírás során épülő identitás vizsgálata azért fontos, mivel elvezet a blogoló szülők tanulási gyakorlatainak/folyamatainak elemzéséhez is. A más emberek vagy közösségek gyakorlatával azonosulás magával vonja a részvételt új beszélgetésekben, és ez a részvétel tanuláshoz vezethet. ${ }^{1}$

\section{VIZSGÁLATI CÉL}

A kutatás célja szívelégtelenségről szóló blogokban és interjúkban a saját tapasztalatok megosztása által megjelenő identitás kialakulásának vizsgálata és értelmezése, különös tekintettel a szülői szerepre és felelősségre, ami az egészségmúveltség részét képezi.

\section{MÓDSZER}

A kvalitatív diskurzusanalízisen alapuló vizsgálat 13 blogot és 6 mélyinterjút tartalmazott, amelyeket a blogot író szülőknek feltett, nyitott kérdésekkel vettek fel. Az adatokat 2015. február és 2016. március között töltötték le. A gyermekek életkora újszülöttől általános iskolásig terjed, különböző fokú és stádiumú szívelégtelenségben szenvednek, eltérő gazdasági, edukációs és szociokulturális háttérrel rendelkeznek. A kutatók ATLAS.ti szoftvert használtak a tematikus analízisre. Az írói identitást a korábban leírt négy részre bontották, valamint négy fő tartalmi típust azonosítottak a blogokban: a szülók mindennapi élete a gyerekkel, az orvosi tények, az elköteleződés és az érzelmek kifejezése.

A négy tartalmi típushoz különböző funkciók tartozhatnak, például információmegosztás az orvosi tényeket tartalmazó szövegben, problémameg- oldás a mindennapi teendők és kihívások kapcsán, valamint kampányolás, ami az elköteleződéshez köthető. Az érzelmekről szóló szövegek pedig értelmezhetőek információmegosztásként és problémamegoldásként egyaránt.

\section{EREDMÉNYEK}

1. A leggyakoribb tartalmi típus a „szülők mindennapi élete a gyerekkel”. Itt megjelenhet a szülői nézőpont, ami kiegészíti az egészségügyi ellátást, kezelést és gyógyszereket, valamint az „életrajzi én”, amit a korábbi tapasztalatok és az egészségműveltségi szokások formálnak, amely által felkészült, gondoskodó szülóként jelenik meg az író, bemutatva a mindennapi élet pozitív és negatív oldalát is. Az identitás szövegkörnyezettől függően változva jelenhet meg, egyes helyzetekben gondoskodó, de az orvosi személyzettől függő, máskor független, tudatos és felkészült önazonosságként is.

Példa: "Emma gets cold very easily...When we come indoors we need to flush hands and feet in hot water for a long time. Or give her a bath" "Emma könnyen áthül... Amikor bejövünk, hoszszú ideig kell meleg vízben áztatni a kezeit és a lábait. Vagy meg kell fürdetnünk."

2. Az „orvosi tények” megosztása típus tudatos tanulást foglal magában, ezáltal egy olyan jól informált személy rajzolódik ki a szövegből, aki rendelkezik az információ feldolgozásának képességével. Itt a szerzői én/identitás relevánssá válik, mivel az interneten vagy az egészségügyi személyzettől szerzett tudásra több esetben autoriter módon hivatkoznak, "egyértelmúként" és "ismertként" közölve, ezáltal mellőzve az információ forrását. Más esetben az írók hivatkozhatnak külső forrásokra, "tekintélyekre" (pl. akadémiai folyóirat); ilyenkor megjelenhet a korábbi akadémiai háttérrel és kritikai gondolkodással rendelkező „életrajzi én”.

Példa: "...I'm pretty critical when I gather the facts. I have an academic education and I use critical thinking..." - "Nagyon kritikus vagyok, amikor tényeket gyűjtök. Egyetemi végzettségem van, és kritikusan gondolkodom..." 
3. A kollektív cselekvésként felfogható „elköteleződés” típus egy nagyobb "célért" vagy "küldetésért" jelenik meg (pl. pénzgyűjtés, segélynyújtás), ami túlmutat a saját szülői szerepen. A pénzgyűjtés során aktív részt vállalva, egy nagyobb közösség részeként képes az összes szívbeteg gyerekért cselekedni, ellensúlyozva a gyereke hospitalizációja során megélt függőséget.

Példa: "...but it is just that these statistics are not talked about, because only children with cancer count, really, of course that is horrible too but they are not as many if you compare and heart children are not talked about." - "...de csak arról van szó, hogy ezekről a statisztikákról nem beszélnek, mert csak a rákos gyerekek számítanak, tényleg, persze az is borzalmas, de nincsenek olyan sokan, ha összehasonlítod, és a szívbeteg gyerekekről nem beszélnek."

4. Az identitás formálódhat az „érzelmek kifejezése” típus megosztása során is. Egyformán megjelenhet a szövegben az erős és aktív, de törékeny és érzelmileg túlterhelt szerep is. A blogírás okaira reflektálva a szerzők megemlítik az írás "szükségességét", a terápiás és felszabadító hatását. Sok esetben a szülők mások emocionális tapasztalataira is kíváncsiak, ezáltal készülve fel a jövőre.
Példa: "I definitely get therapy from writing. I mean I felt relieved ('lättad') when I had written a blog post" - "Az írás kifejezetten gyógyító hatású számomra. Úgy értem, hogy megkönnyebbültem, amikor megírtam egy posztot a blogon."

\section{DISZKUSSZIÓ}

A blogíró képes váltani a két ellentétes identitás között különböző, illetve ugyanazon szövegen belül is. A szülő nemcsak azt tudja, mit kell tenni a szívproblémával küzdő gyermek ápolásáért, hanem azt is, milyen érzés ilyen szülőnek lenni. A szövegből kirajzolódó identitása az információ kritikus gyűjtője és laikus elemzője, aki a tényeket összehasonlítva lehetővé teszi a személyes tapasztalaton túlmenő tudásépítést.

Annak érdekében, hogy a széleskörü és megbízható információt szolgáltató „szerzői én” kialakuljon, az írónak tovább kell tekintenie személyes helyzetén. A szívproblémákról és az ezekkel együttélésről szóló tények bemutatásán túl a szülők írásaikban új tudást is megjelenítenek arról, hogy kik ők szülőként és emberként. Az írás a blogoló szülők számára az események és adatok feldolgozásának egy módját jelenti, de egy közösségbe való belépést is, és mindkét tevékenység tanuláshoz, ezáltal pedig új tudáshoz vezethet.

\section{TANULSÁGOK A HAZAI SZAKEMBEREK SZÁMÁRA}

Az írás terápiás hatása mellett a blogírás hozzájárulhat ahhoz, hogy az egyén új közösségbe csatlakozhasson, és új tudást elsajátítson el, ami szükséges az egészségműveltség növeléséhez. A blogokban megjelenő identitások kialakulásának vizsgálata elősegíti a társadalom egészségműveltségi szokásainak és gyakorlatának mélyebb megértését.

\section{HIVATKOZÁSOK}

${ }^{1}$ E Wenger. Communities of Practice: Learning, Meaning, and Identity. Cambridge University Press, Cambridge, 1998. 